\title{
MODEL EVALUASI PEMBELAJARAN PADA MASA NEW NORMAL: STUDI KASUS DI SDN 04 KALISARI KABUPATEN GROBOGAN
}

\author{
Nada Nurfadhilah \\ Universitas Islam Indonesia, Yogyakarta, Indonesia \\ 19422154@students.uii.ac.id
}

Ahmad Alkindi Siregar

Universitas Islam Indonesia, Yogyakarta, Indonesia 19422173@students.uii.ac.id

\section{Vira Muthia Rabi'ah}

Universitas Islam Indonesia, Yogyakarta, Indonesia 19422186@students.uii.ac.id

\section{Burhan Nudin \\ Universitas Islam Indonesia, Yogyakarta, Indonesia burhannudin@uii.ac.id}

DOI: 10.20885/tarbawi.vol12.iss2.art3

\begin{abstract}
Since Covid-19, schools implement the online learning system which gives extra tasks and responsibilities to all teachers. In online learning, the implementation of formative and summative evaluations has several problems, one of which is the limitations of media and learning evaluation tools. The purpose of this study is to explain and analyze (1) the implementation of summative and formative tests before the pandemic (2) the implementation of summative and formative tests during the new normal (3) The obstacles and supporting factors of the evaluation process at SDN 04 Kalisari. The research uses a qualitative approach. The data collection technique was carried out by indirect observation through the website, interviews via Zoom, and the study of documentation obtained in the form of data on school facilities and infrastructure. The technique of determining the informants used purposive sampling, namely the Principal and
\end{abstract}




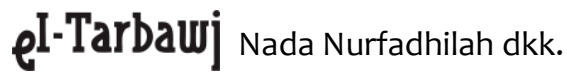

Teachers. The data analysis technique uses the Miles and Huberman model by means of data reduction, data presentation, and drawing conclusions. The conclusion of this study is that the implementation of formative and summative learning evaluations provides new achievements or new challenges for principals and teachers (1) The use of various learning methods to increase student interest (2) Smartphone and unstable network constraints (3) decreased student scores.

Keywords: Management; Evaluation; Learning; Pandemic

\section{Abstrak}

Sejak Covid-19, pembelajaran menerapkan pembelajaran daring yang memberikan tugas dan tanggung jawab ekstra terhadap semua guru. Dalam pembelajaran daring, pelaksanaan evaluasi pembelajaran formatif dan sumatif, memiliki beberapa permasalahan, salah satunya adalah keterbatasan media dan alat evaluasi pembelajaran. Tujuan dari penelitian ini adalah untuk menjelaskan dan menganalisis (1) implementasi tes sumatif dan formatif sebelum pandemi (2) implementasi tes sumatif dan formatif pada masa new normal (3) Faktor penghambat dan pendukung proses evaluasi di SDN 04 Kalisari. Penelitian menggunakan pendekatan kualitatif. Teknik pengumpulan data dilakukan dengan observasi secara tidak langsung melali website, wawancara melalui Zoom, dan studi dokumentasi yang diperoleh berupa data sarana dan prasarana sekolah. Teknik penentuan informan menggunakan purposive sampilng yakni Kepala Sekolah dan Guru. Teknik analisis data menggunakan model Miles dan Huberman dengan cara reduksi data, penyajian data, dan penarikan kesimpulan. Simpulan dari penelitian ini ialah pelaksanaan evaluasi pembelajaran formatif dan sumatif memberikan capaian baru atau tantangan baru bagi kepala sekolah dan guru (1) Penggunaan berbagai metode pembelajaran untuk meningkatkan minat peserta didik (2) Kendala smartphone dan jaringan tidak stabil (3) Menurunnya nilai peserta didik

Kata Kunci: Manajemen; Evaluasi; Pembelajaran; Pandemi 


\section{PENDAHULUAN}

Sebagai lembaga pendidikan formal, sekolah memiliki peran besar dalam proses tranfer pengetahuan. Guru harus selalu berusaha memberikan pengetahuan yang cukup serta pembelajaran yang menarik minat dan bakat peserta didik (Nurhastuti, 2019). Hal tersebut merupakan kondisi ideal dalam dunia pendidikan sebelum Pandemi Covid-19 membatasi ruang gerak kehidupan secara keseluruhan. Sejak Maret 2020, pembelajaran di sekolah dilakukan secara daring. Pembelajaran tatap muka di sekolah bergeser menjadi pembelajaran tatap maya atau tatap layar. Hal ini dilakukan dalam rangka memutus rantai penyebaran virus Corona, guna mematuhi aturan Pembatasan Sosial Berskala Besar (PSBB) (Hafida, 2020).

Pembelajaran daring dimaknai dengan pembelajaran yang memanfaatkan jaringan internet. Dalam pelaksanaannya, pembelajaran daring memiliki keleluasaan waktu belajar, sehingga dimanapun dan kapanpun peserta didik dapat belajar selama memiliki jaringan internet. Proses pembelajaran daring ini dapat menggunakan aplikasi seperti classroom, video conference, live chat dan lain-lain. Aplikasi ini merupakan inovasi pembelajaran dalam menjawab tantangan ketersediaan sumber belajar yang variatif. Dalam proses pembelajaran daring ini, keterlibatan orangtua diperhitungan sebagai suksesi pembelajaran. Selain itu juga keberhasilan pembelajaran tidak hanya ditentukan oleh modeol atau media belajar namun juga karakteristik peserta didiknya (Wijaya et al., 2021). 


\section{$e^{\text {I-Tarbawj Nada Nurfadhilah dkk. }}$}

Di sisi lain, pembelajaran daring memberikan tantangan baru bagi guru karena pembelajaran tersebut memberikan pekerjaan tambahan bagi guru dalam mengamati atau mengobservasi perkembangan etika, tanggungjawab, dan karakter peserta didik. Selanjutnya, kendala penguasaan teknologi dan jaringan internet menjadi salah satu hambatan guru dalam melangsungkan pembelajaran daring ini. Seolah guru diharuskan melakukan inovasi pengintegrasian pendidikan karakter dalam pembelajaran daring (Van Loon et al, 2021). Tantangan, hambatan, dan masalah-masalah yang akan muncul saat pelaksanaan pembelajaran daring dari segi sistem hingga ke proses evaluasi harus dapat diatasi oleh pihak institusi pendidikan. Pencarian solusi dari semua permasalahan yang akan muncul bukan sekedar menjadi tanggung jawab pemerintah, akan tetapi juga harus menjadi perhatian oleh masyarakat Indonesia.

Pelaksanaan pembelajaran di kelas mengandung proses pengembangan karakter peserta didik. Proses ini saling berkaitan antara pengetahuan dan nilai-nilai perilaku dengan sikap dan emosi peserta didik. Hal-hal tersebut dapat dinamai dengan komponen karakter. Dengan kata lain, semakin lengkap komponen moral dimiliki oleh peserta didik, akan semakin membentuk karakter yang baik dan tangguh/unggul (Arikunto, 1988). Disamping pengembangan karakter tersebut, evaluasi pembelajaran juga memberikan kesempatan kepada peserta didik untuk meningkatkan kemampuannya.

Evaluasi sebagai salah satu komponen inti dalam kurikulum merupakan kegiatan mendasar bagi pengembangan kurikulum mikro dalam hal ini evaluasi pembelajaran di kelas. 
Evaluasi sering dipahami hanya terbatas pada penilaian formatif dan sumatif saja. Ketika sudah dilakukan penilaian, dianggap sudah melakukan evaluasi. Seharusnya evaluasi tidak terbatas pada tercapainya tujuan, artinya bukan hanya nilai yang dilihat, tetapi ada faktor-faktor lain yang membuat berhasil atau tidaknya suatu tujuan pembelajaran itu. Sehingga hasil evaluasi dapat digunakan sebagai landasan kebijakan tindak lanjut dari proses pembelajaran secara mikro dan pengembangan kurikulum secara menyeluruh. Menurut $M$. Arifin yang dikutip oleh Abdullah Idi menyampaikan bahwa rumusan tujuan pendidikan Islam yaitu mewujudkan pribadi muslim yang beriman, bertakwa, dan berilmu yang dapat mengabdikan diri kepada Tuhan dengan tawakkal kepada-Nya dan mencari Ridho-Nya dalam aspek kehidupan (Idi, 2014).

Dengan keadaan pandemi sejak 2020, maka proses evaluasi menjadi semakin bervariasi. Guru dituntut tidak hanya mencapai tujuan pembelajaran yang pengetahuan (kognitif), namun juga sikap (afeksi dan psikomotorik). Oleh karena itu, peneliti teratik untuk mengetahui implementasi tes sumatif dan formatif pada masa sebelum pandemi, new normal serta faktor pendukung dan penghambat proses evaluasi yang dilakukan sekolah. Pada kesempatan ini peneliti melaksanakan penelitian di SDN 04 Kalisari Kabupaten Grobogan. Berdasarkan hal tersebut, maka fokus pada penelitian ini adalah bagaimana pelaksanaan model evaluasi pembelajaran di SDN 04 Kalisari Kabupaten Grobogan pada masa sebelum dan saat pandemi Covid-19. 


\section{$e^{I-T a r b a w j}$ Nada Nurfadhilah dkk.}

\section{METODE PENELITIAN}

Penelitian yang berjudul yang berjudul Model Evaluasi Pembelajaran Pada Masa New Normal: Studi Kasus di SDN 04 Kalisari Kabupaten Grobogan, menggunakan pendekatan kualitatif. Pendekatan kualitatif adalah metode penelitian yang bersifat deskriptif dan menggunakan analisis dari data yang diperoleh tanpa melalui prosedur statistik. Melalui pendekatan kualitatif ini dapat diketahui bagaimana implementasi tes sumatif dan tes formatif pada masa pembelajaran sebelum pandemi, new-normal serta apa saja yang menjadi faktor penghambat dan pendukung dalam proses evaluasi di SDN 04 Kalisari Kabupaten Grobogan.

Subjek dari penelitian yang kami gunakan adalah SDN 04 Kalisari yang berlokasi di Jl. Raya Kuwu-Kradenan, Kalisari, Kec. Kradenan, Kab. Grobogan, Prov. Jawa Tengah. Peneliti memilih lokasi tersebut karena terdapat masalah yang terjadi ketika melakukan pembelajaran daring dan menjadikan alasan itu sebagai objek yang kami teliti yaitu model evaluasi sumatif dan formatif pada masa new normal. Selanjutnya teknik sampling yang digunakan dalam penelitian ini adalah teknik purposive sampling dimana cara pengambilan sampel dengan menentukan kriteria-kriteria tertentu, dalam penelitian ini yang menjadi informan adalah kepala sekolah dan guru kelas. 
Berikut adalah langkah-langkah untuk melakukan penelitian ini:

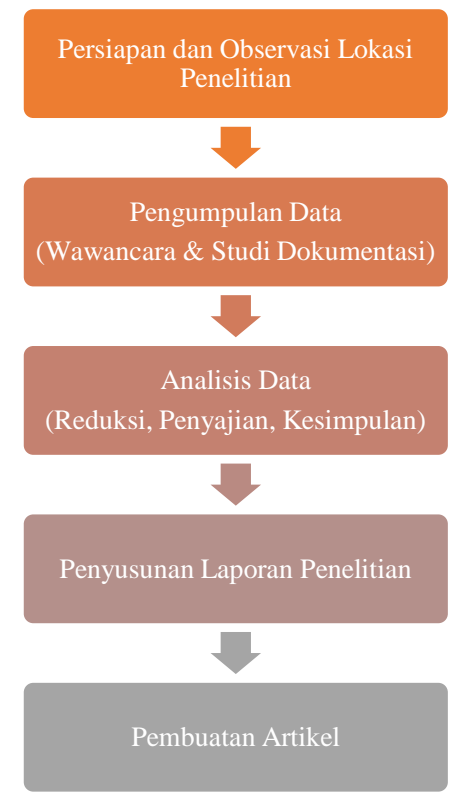

GAMBAR 1. Prosedur Pelaksanaan Penelitian

Teknik pengumpulan data dalam penelitian ini adalah dengan melakukan observasi, wawancara dan studi dokumentasi. Observasi adalah salah satu teknik untuk mengumpulkan data dengan cara melakukan pengamatan secara langsung. Pada penelitian ini, observasi dilakukan secara tidak langsung menggunakan peralatan elektronik dan jaringan internet untuk mengamati kondisi yang terjadi di SDN 04 Kalisari Kab. Grobogan melalui website yang tersedia. Observasi tidak langsung adalah observasi yang dilakukan tidak pada saat berlangsungnya suatu pengamatan objek penelitian, misalnya dilakukan melalui film, rangkaian slide, dan foto. Wawancara adalah teknik pengumpulan data dengan cara interaksi dan komunikasi verbal secara langsung dengan 


\section{$e^{I-T a r b a w j ~ N a d a ~ N u r f a d h i l a h ~ d k k . ~}$}

informan yang bertujuan untuk menemukan informasi lebih lanjut terkait objek yang diteliti. Untuk melakukan wawancara, peneliti menggunakan teknik wawancara terstruktur agar pertanyaan dan alternatif jawaban sudah ditetapkan, sehingga akan mempermudah pengelompokan dan proses analisis datanya. Untuk mendapatkan informasi tersebut maka peneliti mengajukan beberapa pertanyaan kepada informan secara lisan dan dijawab secara lisan pula. Dalam hal ini, peneliti menentukan kepala sekolah dan guru pengajar sebagai informan yang akan memberikan informasi terkait kondisi di SDN 04 Kalisari. Studi dokumentasi adalah teknik pengumpulan data dengan menggunakan dokumen tertulis yang dimiliki untuk mencari informasi terkait objek yang sedang diteliti seperti arsip, kurikulum yang ada di sekolah dan lainnya. Dalam penelitian ini, peneliti menggunakan website untuk melihat profil SDN 04 Kalisari Kab. Grobogan meliputi data tenaga pendidik, peserta didik, sarana dan prasarana, letak gambaran umum dan kondisi sekolah.

Adapun instrumen yang mendukung untuk melakukan penelitian ini antara lain: 
TABEL 1. Instrumen Pendukung Penelitian

\begin{tabular}{|l|l|l|}
\hline No. & \multicolumn{1}{|c|}{ Alat } & \multicolumn{1}{c|}{ Fungsi } \\
\hline 1. & $\begin{array}{l}\text { Daftar } \\
\text { pertanyaan }\end{array}$ & $\begin{array}{l}\text { Tersedia beberapa pertanyaan yang akan } \\
\text { diajukan ketika wawancara virtual melalui } \\
\text { zoom dengan kepala sekolah dan guru di } \\
\text { SDN 04 Kalisari Kab. Grobogan mengenai } \\
\text { evaluasi pembelajaran pada masa new } \\
\text { normal. }\end{array}$ \\
\hline 2. & Laptop & $\begin{array}{l}\text { Perangkat keras yang digunakan untuk } \\
\text { melakukan wawancara virtual melalui } \\
\text { zoom dan foto dokumentasi dari rumah } \\
\text { masing-masing peneliti. }\end{array}$ \\
\hline 3. & Zoom meeting & $\begin{array}{l}\text { Media online yang digunakan untuk } \\
\text { melakukan wawancara jarak jauh dengan } \\
\text { informan yang sudah ditentukan. }\end{array}$ \\
\hline 4. & Buku catatan & $\begin{array}{l}\text { Digunakan untuk mencatat semua } \\
\text { informasi yang diterima ketika melakukan } \\
\text { wawancara dengan informan. }\end{array}$ \\
\hline
\end{tabular}

Analisis data adalah suatu proses untuk menyusun, mengorganisasikan dan mengurutkan data-data yang sudah diperoleh ke dalam beberapa bagian untuk mengetahui hubungan antara data yang satu dengan lainnya, sehingga akan memudahkan peneliti dalam mengambil suatu kesimpulan. Teknik analisis data yang digunakan dalam penelitian ini ialah model Miles dan Huberman yang terdiri dari tiga tahap, tahap pertama yaitu tahap reduksi data, di tahap ini merupakan tahapan dimana merupakan suatu proses pemilihan, pemusatan perhatian dan juga penyederhanaan dari data-data lapangan yang didapatkan, tahap kedua yaitu tahap penyajian data yaitu tahap dimana hasil dari pengumpulan data di lapangan disusun lebih sistematis, serta hasil reduksi data dapat dijelaskan atau ditampilkan menggunakan matriks, 


\section{$e^{\text {I-Tarbawj Nada Nurfadhilah dkk. }}$}

bagan, grafik, dan jaringan. Dan tahap ketiga adalah penarikan kesimpulan, kegiatan ini berfungsi untuk mencari makna data yang sudah disajikan dengan membandingkan kesesuaian antara pernyataan dengan konsep dasar dalam penelitian, sehingga dapat dilakukan penarikan kesimpulan yang tujuannya untuk menyimpulkan dari semua data yang sudah disajikan (Humberman, 1992).

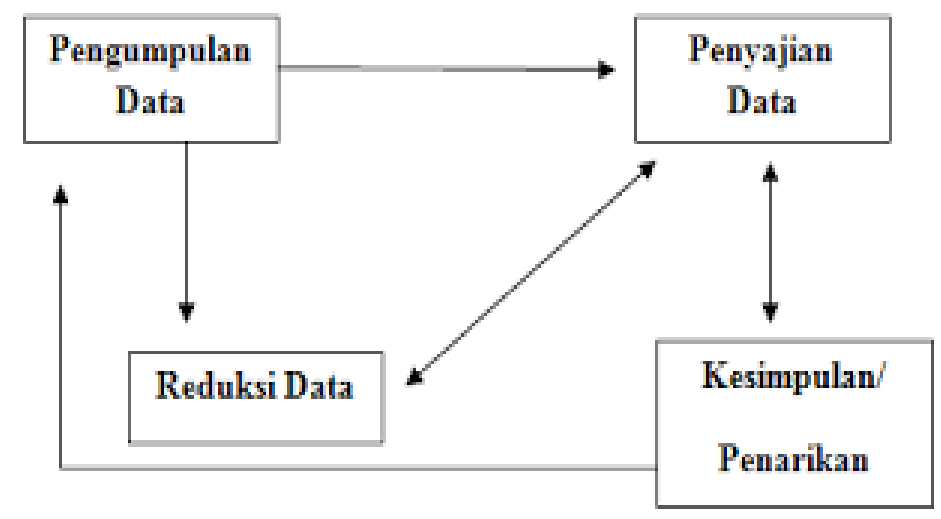

GAMBAR 2. Alur Analisis Data Kualitatif Miles dan Huberman

\section{HASIL DAN PEMBAHASAN}

Implementasi Pelaksanaan Evaluasi Pembelajaran pada Masa Sebelum Pandemi Covid-19 di SDN 04 Kalisari Kabupaten Grobogan

Evaluasi adalah suatu proses yang dimana keputusan penilaian (value judgement) tidak hanya didasarkan kepada hasil pengukuran(quantitative description), tetapi juga didasarkan kepada hasil pengamatan (qualitative description) (Widiyanto, 2018). Evaluasi pembelajaran dapat dibagi menjadi 
tiga domain hasil belajar, domain kognitif, domain afektif, dan domain psikomotorik. Domain kognitif berisi tentang pengetahuan, pemahaman, penerapan, analisis, sintesis, dan evaluasi. Kemudian dalam ranah afektif berisi mengenai kemampuan menerima, kemampuan menanggapi, menilai, dan organisasi. Dan yang terakhir adalah domain psikomotorik yang berkaitan dengan gerakan-gerakan tubuh, dari gerakan yang sederhana hingga gerakan yang kompleks (Rukajat, 2018). Ketiga domain hasil tersebut harus terus dievaluasi untuk mendapatkan hasil belajar peserta didik yang baik. Evaluasi pembelajaran dikatakan berhasil bukan hanya dapat mengetahui data-data atau informasi mengenai kekurangan peserrta didik, melainkan bagaimana data-data atau informasi menjadi landasan untuk membuat solusi dan mengimpelementasikannya.

Evaluasi pembelajaran sebelum pandemi covid-19 adalah evaluasi yang dilaksanakan sebagaimana pelaksanaan evaluasi pada umumnya. Implementasi evaluasi adalah sesuatu yang wajib dilakukan dalam sebuah sekolah. Jika itu dalam proses pembelajaran, berarti objek yang akan dievaluasi adalah peserta didik. Dalam implementasinya, evaluasi pembelajaran dapat diharapkan dapat menjadi informasi berupa data-data yang menjadi landasan bagi progres perkembangan pembelajaran peserta didik. Tentunya data-data tersebut akan menjadi standar dalam perbaikan dan pengayaan untuk perkembangan pembelajaran peserta didik.

Implementasi pelaksanaan evaluasi pembelajaran pada masa sebelum pandemi covid-19 di SDN 04 Kalisari Kabupaten Grobogan berjalan dengan semestinya. Dari evaluasi formatif 


\section{$e^{I-T a r b a w j}$ Nada Nurfadhilah dkk.}

berupa latihan-latihan soal, praktek pembelajaran, dan penilaian sikap hingga evaluasi sumatif berupa ujian kenaikan kelas dengan tes tulis maupun praktek dapat berjalan dengan baik. Dalam hal ini guru-guru di SDN 04 Kalisari Kabupaten Grobogan juga lebih mudah dalam memantau perkembangan pembelajaran peserta didik. Evaluasi pembelajaran yang dilaksanakan oleh SDN 04 Kalisari Grobogan bertujuan untuk mengecek hasil belajar peserta didik apakah ada kekurangan atau tidak dalam proses pembelajaran, mencari solusi dari kekurangan yang peserta didik alami dan juga menyimpulkan seberapa menguasainya peserta didik dalam materi-materi yang disampaikan oleh para guru.

Sebelum masa pandemi Covid-19, evaluasi pembelajaran terhadap domain belajar kognitif, afektif, dan psikomotorik SDN 04 Kalisari Kabupaten Grobogan berjalan secara tatap muka yang dimana evaluasi pembelajaran akan lebih efektif dan efisien, khususnya pada evaluasi afektif dan psikomotorik. Pada aspek afektif, sikap peserta didik dapat dinilai secara langsung dari bagaimana cara sikap peserta didik didalam kelas maupun diluar kelas (jam istirahat) dan juga sikap peserta didik terhadap teman-teman sebayanya. Sama halnya dengan aspek psikomotorik, penilaian dapat berjalan dengan lebih efektif karena dinilai secara langsung. Guru-guru SDN 04 Kalisari Kabupaten Grobogan juga lebih percaya diri dalam hasil pembelajaran peserta didik jika proses pembelajaran dilakukan secara tatap muka.

Akan tetapi, proses evaluasi pembelajaran yang dijelaskan di atas mengalami perubahan saat masa pandemi Covid-19 dimulai. Setiap sekolah tidak diizinkan melaksanakan proses 
pembelajaran secara langsung (tatap muka). Pemerintah memberikan aturan untuk melakukan pembelajaran dengan daring, sehingga baik dari proses penyampaian materi hingga evaluasi pembelajaran mengalami perubahan, dan itu sulit bagi mayoritas sekolah yang ada di Indonesia, termasuk SDN 04 Kalisari Kabupaten Grobogan. Sekolah yang berada di perbatasan antara desa dengan kota ini tentu tidak semua peserta didik maupun guru memiliki media teknologi yang dapat mendukung dalam proses pembelajaran daring.

\section{Implementasi Pelaksanaan Evaluasi pada Masa Pandemi Covid-19 di SDN 04 Kalisari Kabupaten Grobogan}

Menurut Achmad Yurianto selaku Juru Bicara Penanganan Covid-19 menyatakan bahwa masyarakat harus menjaga produktivitas di tengah pandemi Covid-19 dengan tatanan baru yang disebut sebagai New Normal. Tatanan baru ini adalah bentuk kebiasaan baru masyarakat untuk beradaptasi dengan membudayakan perilaku hidup bersih dan sehat seperti rutin cuci tangan pakai sabun, menggunakan masker saat keluar rumah, jaga jarak, dan menghindari kerumunan. Di dalam dunia pendidikan, tentu tidak akan mungkin untuk melakukan pembelajaran tatap muka secara langsung di dalam kelas, sehingga langkah yang mungkin untuk bisa dilakukan oleh sekolah ialah melakukan pembelajaran daring dan hybrid bagi sekolah yang tidak mampu untuk melakukan pembelajaran daring sepenuhnya karena alasan tertentu.

Proses pembelajaran yang dilakukan di SDN 04 Kalisari adalah pembelajaran daring dengan menggunakan berbagai 


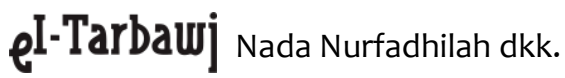

metode agar materi yang disampaikan guru dapat dengan mudah diterima oleh peserta didik. Adapun metode yang digunakan oleh guru dalam proses pembelajaran di antaranya adalah metode ceramah, tanya jawab, memberikan tugas rumah dan menggunakan alat praktik yang konkret dan nyata untuk menarik minat belajar peserta didik, khususnya peserta didik kelas bawah. Metode tanya jawab dan pemberian tugas yang diberikan kepada peserta didik ini dapat dijadikan sebagai evaluasi pembelajaran yang dilakukan oleh guru di dalam kelas, evaluasi pembelajaran yang digunakan ini adalah evaluasi formatif dan sumatif.

Tentunya metode yang digunakan ini belum dapat berjalan secara sempurna dikarenakan ada beberapa kendala yang dialami seperti sinyal tidak stabil, tidak siapnya guru untuk belajar daring serta mengoperasikan zoom meeting, dan peserta didik yang tidak memiliki smartphone untuk belajar sehingga tidak mampu mengikuti proses pembelajaran. Sehingga untuk mendukung keberlangsungan proses dan evaluasi pembelajaran daring agar berjalan dengan baik, Kepala Sekolah SDN 04 Kalisari mewajibkan guru untuk memiliki laptop pribadi dan jika tidak memungkinkan maka sekolah mampu menyediakan tiga sampai lima laptop untuk digunakan sebagai alat pembelajaran secara bergantian.

Kesiapan guru dalam proses pembelajaran di SDN 04 Kalisari juga harus diperhatikan. Sebab tentunya, proses pembelajaran sekarang tentunya jauh berbeda dengan pembelajaran sebelumnya. Maka Kepala SDN 04 Kalisari melakukan beberapa hal untuk mempersiapkan guru agar pembelajaran daring dapat terlaksana dan juga tersampaikan 
dengan baik, yaitu dengan cara memberikan pengarahan atau briefing kepada guru oleh Kepala Sekolah guna untuk memberikan kesiapan guru dalam melangsungkan pembelajaran daring. Dan antar guru saling memberikan support satu sama lain agar tidak bosan-bosannya untuk memberikan rangsangan kepada siswa agar tidak bosan untuk belajar (Ina Magdalena H. M., 2020)

Terdapat tiga aspek yang dievaluasi dalam proses pembelajaran yakni aspek kognitif, afektif, dan psikomotorik. Ketiga aspek inilah yang nantinya akan menentukan apakah peserta didik mampu menerima materi yang disampaikan oleh guru selama pembelajaran daring serta menilai kemampuan guru dalam mengevaluasi peserta didik dari jarak jauh. Sehingga, evaluasi secara online ini membuat guru dan Kepala sekolah sebagai pimpinan sekolah untuk terus berusaha keras agar peserta didik mampu berkembang dengan baik dan mencapai tujuan pembelajaran dari sekolah tersebut.

Pelaksanaan evaluasi online dalam aspek kognitif peserta didik di SDN 04 Kalisari dilakukan dengan memberikan tugas dan praktikum menggunakan alat yang tersedia di lingkungan sekitar peserta didik. Namun, dalam pelaksanaannya tidak semua peserta didik mengerjakan tugas tersebut secara mandiri. Begitu juga dengan aspek afektif atau sikap dan nilai, penilaian sikap diartikan bahwa setiap peserta didik memiliki perilaku yang baik. Penilaian sikap baik buruknya nilai tergantung indikator penilaian yang telah ditentukan oleh pihak sekolah. Perilaku sangat baik atau kurang baik yang dijumpai selama proses pembelajaran dimasukkan ke dalam jurnal atau catatan observasi guru (Ediana, 2018). Pada 


\section{$e^{I-T a r b a w j ~ N a d a ~ N u r f a d h i l a h ~ d k k . ~}$}

penilaian sikap yang dilaksanakan oleh SDN 04 Kalisari Kabupaten Grobogan, para pendidik atau guru memperhatikan keaktifan siswa saat menghadiri dan juga mengikuti proses pembelajaran melalui media zoom, mengumpulkan tugas tepat waktu, dan disiplin dalam hadir saat jadwal yang diberikan. Penilaian sikap secara online ini tentunya masih kurang efektif karena terkendala jarak, tetapi dengan adanya kendala seperti ini memudahkan guru untuk menilai apakah sikap peserta didik di rumah sikapnya sama dengan seperti sikapnya di sekolah. Sedangkan aspek psikomotorik masih sangat terkendala oleh praktikum yang harus dilakukan seperti pada mata pelajaran olahraga.

\section{Faktor Penghambat dan Pendukung Proses Evaluasi di SDN 04 Kalisari Kabupaten Grobogan}

Evaluasi merupakan pengumpulan bukti-bukti yang cukup untuk dijadikan sebuah dasar penetapan ada atau tidaknya perubahan yang terjadi pada anak didik. Dengan perubahan-perubahan yang terjadi pada peserta didik, pendidik dapat menjadikan perubahan-perubahan tersebut menjadi dasar untuk perbaikan ataupun penambahan materi kepada peserta didik. Jenis evaluasi yang sering digunakan di sekolah yang menjadi objek observasi yaitu jenis evaluasi formatif dan sumatif (Ina Magdalena H. M., 2020). Dalam pelaksanaan evaluasi pembelajaran secara daring yang dilaksanakan oleh SDN 04 Kalisari Kabupaten Grobogan, baik evaluasi sumatif maupun formatif tentu memiliki faktor penghambat dan pendukung dalam proses evaluasi pembelajaran daring. 
Kendala ataupun hambatan dalam pembelajaran adalah beberapa permasalahan yang menghambat jalannya pembelajaran yang dilihat dari faktor manusiawi (guru dan peserta didik), faktor institusional (ruang kelas), dan intruksional (kurangnya alat peraga) (Proborini, 2021). Pada pelaskanaan evaluasi pembelajaran baik formatif maupun sumatif, SDN 04 Kalisari Kabupaten Grobogan, memiliki beberapa permasalahan ataupun hambatan dalam pelaksanannya, salah satunya adalah dari media dan alat evaluasi pembelajaran dari handphone maupun laptop yang tidak semua peserta didik memilikinya, sehingga sulit bagi pihak sekolah untuk menyampaikan materi dalam proses pembelajaran yang akan diberikan.

Di sisi lain SDN 04 Kalisari Kabupaten Grobogan saat memberikan evaluasi berupa tes tulis dalam bentuk penugasan kepada siswa, tidak jarang tugas yang diberikan oleh para guru yang mengerjakannya adalah orang tua siswa. Sehingga hal tersebut secara langsung juga menimbulkan penurunan prestasi siswa yang semula pada saat pembelajaran tatap muka materi bisa tersampaikan secara langsung menjadi sulit untuk sampai kepada pemahaman siswa.

Dengan adanya evaluasi ini yaitu bertujuan untuk membantu peserta didik dimasa pandemi agar dapat mengetahui tingkat pencapaian siswa dalam suatu proses pembelajaran, serta untuk memahami sejauh mana siswa dapat memahami suatu pembelajaran tersebut. Evaluasi dapat memberikan bantuan dalam melihat dan juga memantau kekurangan dan kelebihan siswa, dengan tujuan untuk menempatkan siswa pada situasi belajar yang lebih tepat sesuai 


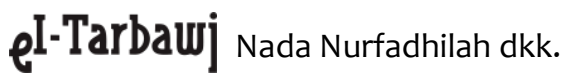

dengan yang diharapkan seperti sebelum adanya masa pandemi seperti sekarang yang membatasi peserta didik dalam melakukan proses belajar dengan tingkat kemampuan yang mereka miliki.

Dari hasil observasi di ketahui bahwa evaluasi yang efektif yang digunakan di SDN 04 Kalisari Kabupaten Grobogan ada beberapa macam evaluasi dan metode yang dilakukan oleh para guru yaitu menerangkan kepada peserta didik dengan menggunakan alat yang konkret, kemudian menggunakan juga metode ceramah, tanya jawab, dan juga metode kelompok. Bukan hanya dengan metode tersebut namun juga para guru sepakat untuk melakukan proses pembelajaran luring, agar siswa tersebut tidak bosan dengan pembelajaran online karena pandemi dengan catatan siswa tersebut tetap mematuhi protokol kesehatan dan tidak dalam keadaan sakit. Metode tersebut dapat membantu guru dalam meningkatkan evaluasi pembelajaran peserta didik dan juga menyiapkan peserta didik untuk menghadapi evaluasi baik formatif maupun sumatif.

Walaupun SDN 04 Kalisari Kabupaten Grobogan memiliki hambatan dalam pelaksanaan evaluasi pembelajaran kepada siswanya, akan tetapi pihak sekolah dari guru hingga kepala sekolah selalu berputar otak untuk mencari solusi dalam penyelesaian masalah yang dialami tersebut. Seperti kepala sekolah yang selalu melakukan briefing untuk memberikan kesiapan guru dalam melangsungkan pembelajaran daring. Kemudian juga antar guru memberikan dukungan satu sama lain agar tidak bosan-bosannya untuk memberikan rangsangan kepada siswa agar tidak bosan untuk belajar. Selain itu para 
guru juga aktif berkomunikasi dengan orangtua untuk bekerjasama dalam pengawasan proses pembelajaran daring ini.

Dengan pelaksanannya evaluasi pembelajaran di SDN 04 Kalisari Kabupaten Grobogan ini akhirnya tentu berharap evaluasi dapat bejalan sesuai dengan fungsinya yaitu untuk mengetahui kemajuan peserta didik, menunjang penyusuan rencana oleh peserta didik, dan memperbaiki serta menyempurnakan kembali kemampuan siswa dalam proses pembelajaran (Widiyanto, 2018). Kepala Sekolah SDN 04 Kalisari Kabupaten Grobogan juga berharap pemerintah dapat segera menyelesaikan permasalahan Covid-19 ini, sehingga proses pembelajaran kepada peserta didik di seluruh Indonesia dapat melaksanakan pembelajaran dengan baik dan maksimal.

\section{ANALISIS PEMBAHASAN}

Pembelajaran pada masa pandemi seperti ini tentunya memiliki perbedaan yang sangat signifikan dengan pembelajaran sebelumnya, yaitu pembelajaran tatap muka. Selain terdapat perbedaan proses pembelajaranya juga terdapat hal-hal lain yang muncul dengan diterapkanya pembelajaran daring ini yaitu faktor penghambat pembelajaran daring, kesiapan guru, sistem evaluasi yang berbeda dari yang sebelumnya, dan juga lain-lain.

Berdasarkan wawancara yang telah kami lakukan kemarin dengan narasumber wawancara, yaitu Kepala Sekolah dan juga Guru SDN 4 Kalisari kami menemukan beberapa hal diantaranya adalah proses pembelajaran daring yang berbeda 


\section{$e^{I-T a r b a w j}$ Nada Nurfadhilah dkk.}

dengan sebelumnya. Proses pembelajaran sebelumnya dilakukan dengan cara tatap muka, yaitu peserta didik datang ke sekolah dan juga mengikuti proses pembelajaran atau penyampaian materi di kelas sampai dengan selesainya jam pembelajaran. Akan tetapi kemudian hal itu berubah dikarenakan adanya pandemi seperti ini dan kemudian proses pembelajaran dialihkan menjadi daring dan sesekali juga melakukan proses pembelajaran secara luring dengan memperhatikan protokol kesehatan, keadaan wilayah atau lingkungan sekolah serta adanya kesepakatan dari orang tua peserta didik dan mematuhi aturan yang ditetapkan oleh pemerintah.

Proses pembelajaran daring tentunya berbeda dengan proses pembelajaran sebelumnya. Pembelajaran daring di SDN 4 Kalisari dilakukan dengan metode ceramah yaitu guru menyampaikan materi kepada peserta didik, kemudian juga menggunakan metode Tanya jawab, memberikan tugas rumah kepada anak, serta memberikan alat praktik yang konkret dan nyata yang menarik yang ada di lingkungan sekitar untuk peserta didik kelas bawah., sehingga siswa tidak bosan untuk melakukan pembelajaran. Pada saat sesi atau proses pembelajaran daring berlangsung, dan untuk mendukung proses pembelajaran daring agar berjalan dengan baik di SDN 4 Kalisari maka guru atau tenaga pengajar di SDN 4 Kalisari diwajibkan untuk memiliki perangkat pendukung pembelajaran pada setiap guru.

Kesiapan guru dalam proses pembelajaran di SDN 4 Kalisari juga diperhatikan. Sebab tentunya sebelumnya proses pembelajaranya sedikit berbeda dengan pembelajaran 
sebelumnya. Maka Kepala Sekolah SDN 4 Kalisari melakukan beberapa hal untuk mempersiapkan guru agar pembelajaran daring dapat terlaksana dengan baik, yaitu dengan cara memberikan pengarahan atau briefing kepada guru oleh Kepala Sekolah guna untuk memberikan kesiapan guru dalam melangsungkan pembelajaran daring. Antar guru memberikan support satu sama lain agar tidak bosan-bosanya untuk memberikan rangsangan kepada siswa agar tidak bosan untuk belajar.

Pembelajaran daring tentunya juga mengalami dan juga mendapat kendala atau faktor penghambat baik itu faktor internal maupun faktor eksternal. Terlebih lagi jika dilihat dari segi kondisi di SDN 4 Kalisari yang bisa dibilang desa juga tidak, kota juga tidak. Selain itu juga adanya perbedaan sosial ekonomi, lingkungan,kurangnya peran orang tua dalam pembelajaran daring, tidak adanya fasilitas yang peserta didik miliki seperti peserta didik tidak memiliki Handphone untuk melaksanakan pembelajaran daring. Faktor internal yang dihadapi oleh SDN 4 Kalisari adalah kurangnya kesiapan guru dan juga pembelajaran daring merupakan suatu hal baru bagi guru. Maka dari itu Kepala Sekolah memberikan pengarahan setiap 3 hari sekali untuk memantau perkembangan dan bagaimana proses pelaksanaan pembelajaran terjadi.

Untuk pelaksanaan sistem evaluasi pada masa pembelajaran daring yang dilakukan oleh SDN 4 Kalisari adalah melakukan evaluasi dengan cara memberikan tugas kepada siswa secara bergilir sesuai dengan kelasnya dan juga materi yang diberikan kepada siswa, jadi siswa datang ke sekolah untuk mengambil tugas dan kemudian keesokan 


\section{$e^{I-T a r b a w j ~ N a d a ~ N u r f a d h i l a h ~ d k k . ~}$}

harinya dikumpulkan di sekolah, pada saat pembelajaran luring maka evaluasi yang dilakukan adalah guru berkeliling kelas dan kemudian memberikan dan juga menjelaskan kepada siswa untuk menangani masalah yang terjadi secara langsung.

Dalam evaluasi pembelajaran daring tentunya juga mengalami kendala yaitu diantaranya fasilitas dan sarana dan prasarana yang tidak memadai, dan tidak jarang bahkan tugas yang diberikan oleh guru kepada siswa yang mengerjakan tugas tersebut adalah orang tua siswa. Sehingga hal tersebut secara langsung juga menimbulkan penurunan prestasi siswa yang semula pada saat pembelajaran tatap muka materi bisa tersampaikan secara langsung dan peserta siswa dapat menyerap dan memahami materi secara langsung dan juga banyak siswa yang pada saat melaksanakan evaluasi belum memenuki Kriteria Ketuntasan Minimal (KKM). Akan tetapi evaluasi pada masa pembelajaran daring ini juga memberikan dampak positis kepada siswa yaitu salah satunya adalah siswa dapat terbentuk karakter yang sadar akan tanggung jawab terhadap dirinya sendiri.

Dan dari pihak SDN 4 Kalisari untuk mengatasi permasalahan tentang evaluasi atau peserta didik yang belum mencapai kriteria ketuntasan minimal (KKM) maka guru akan memberikan remedial kepada siswa yang belum mencapai KKM dan apabila siswa yang sudah mencapai KKM maka akan dilakukan pengayaan oleh guru. Maka dari hal tersebut guru dapat mengetahui materi yang disampaikan sudah diterima siswa atau belum. Kesimpulan yang dapat diambil wawancara yang dilakukan oleh peneliti dengan Kepala Sekolah dan Guru SDN 4 Kalisari ini melalui via zoom ialah, pelaksanaan evaluasi 
pembelajaran di SDN 04 Kalisari memberikan capaian baru atau tantangan baru bagi guru untuk lebih mempersiapkan diri dalam menghadapi berbagai macam situasi pada proses pembelajaran yang akan disampaikan kepada para peserta didik.

\section{KESIMPULAN}

Berdasarkan hasil pembahasan dari wawancara yang dilakukan, proses pembelajaran di SDN 04 Kalisari pada masa pandemi memiliki perbedaan signifikan dari sebelumnya, pada saat tatap muka peserta didik datang masuk kelas dan diberikan materi secara langsung namun saat ini para guru menggunakan metode ceramah dan tanya jawab kepada siswasiswi dalam menyampaikan materi. Persiapan yang dilakukan para guru di SDN 04 Kalisari adalah dengan menyediakan media belajar dan alat praktek yang konkret dan nyata agar para siswa tidak bosan, juga kepala sekolah memberikan pengarahan kepada guru dengan briefing setiap tiga hari sekali guna kesiapan mereka dalam mengajar. Adapun penghambat proses evaluasi di SDN 04 Kalisari salah satunya kurangnya alat dan media belajar seperti handphone dan laptop yang tidak semua peserta didik memilikinya. Penulis mengharapkan agar para guru dapat memberikan solusi dan bantuan untuk meningkatkan proses pembelajaran selama daring ini. 


\section{el-Tarbawj Nada Nurfadhilah dkk.}

\section{DAFTAR PUSTAKA}

Asep Ediana Latip. (2018). Evaluasi Pembelajaran di SD dan MI (Perencanaan dan Pelaksanaan Penilaian Hasil Belajar Autentik).

Hafidah, lilih, wilanika, dkk. (2020). Penurunan Motivasi dan Keaktifan Belajar Siswa Selama Pembelajaran Daring di Tengah Pandemi Covid-19. Vol. 2

Idi, Abdullah. (2014). Pengembangan Kurikulum: Teori \& Praktik. Jakarta: Rajawali Pers.

Oosterhof, Albert. (1999). Developing and Using Classroom Assessment. New Jersey: Upper Saddle River.

Proborini, Ellen. (2021). “EVALUASI PEMBELAJARAN MATEMATIKA SECARA DARING PADA SISWA KELAS VI SD KARANGTURI". Intelligentes: Jurnal Pendidikan Fisika dan Sains". Vol. 2, No. 2.

Magdalena ina, Annisa Rachmadan dan Mita Aulia. 2020. PENERAPAN PEMBELAJARAN DAN PENILAIAN SECARA ONLINE DI MASA PANDEMI . Universitas Muhammadiyah Tangerang : Jurnal Edukasi dan Sains, Vol. 2, No. 2.

Magdalena Ina, Hani Melly Mayanti, dan Rizka Surya Putri. (2020). "Evaluasi Belajar Peserta Didik di Sekolah Dasar". Bintang: Jurnal Pendidikan dan Sains, Vol. 2, No. 3.

Mukminah, Hadi Wijaya, Hirlian. (2020). Problematika Pembelajaran Saat Pandemi Covid-19 di Madrasah Ibtidaiyah Nurul Ulum Mertak Tombok. Jurnal Ilmu Sosial dan Pendidikan. Vol. 5, No. 1.

Rukajat, Ajat. (2018). Teknik Evaluasi Pembelajaran. Yogyakarta: Deepublish. 
Van Loon; Yu Ting, Stefan Clermonts; Zimmerman, David. (2021). New Normal Manajemen Program Penguatan Pendidikan Karakter Melalui Pembelajaran Dalam Jaringan dan Luar Jaringan di Masa Pandemi Covid-19

Widiyanto, Joko. 2018. EVALUASI PEMBELAJARAN (Sesuai dengan Kurikulum 2013) Konsep, Prinsip Prosedur. Madiun: Unipma Press.

Nurhastuti. (2019). Pentingnya Pendidikan Bagi Manusia.Jurnal Buana Pengabdian. Vol. 1, No. 1. 